Jurnal Perikanan Pantura (JPP) Volume 1, Nomor 1, Maret 2018

\title{
UJI DAYA HAMBAT SERBUK DAUN KAYU MANIS (Cinnamomum burmanii) TERHADAP BAKTERI Streptococcus agalactiae
}

\author{
Eka Yunita Wulandari' ${ }^{1}$ Endah Sri Redjeki², Firma Fika Rahmawati ${ }^{3}$ \\ ${ }^{1}$ Mahasiswa prodi Budidaya Perikanan, Fakultas Pertanian, Universitas Muhammadiyah Gresik \\ ${ }^{2}$ Dosen Prodi Budidaya Perikanan, Fakultas Pertanian, Universitas Muhammadiyah Gresik \\ Email : eka.wulandari1503@gmail.com, Phone +6282235152550
}

\begin{abstract}
Streptococcus agalactiaeis a bacterium that causes Streptococcosis in tilapia (Oreochromis niloticus). Antibioticis being used efforts to control the disease. Using antibiotics constantly will adversely affect the aquatic environment, bacterial resistance and presence of residues in fish consumption. Another alternative is to use phytopharmaca materials that are natural and environmentally friendly. One of the phytopharmaca materials that can be used is cinnamon (Cinnamomum burmanii) which contains active ingredients such as Saponin, Alkanoid, Tanin, Flavanoid, Sinamaldehid. The purpose of this study was to investigates the effectiveness and the best dose of cinnamon leaves ( $C$. burmanii) as an antibacterial agent for the prevention of $S$. agalactiaeinfection. This research was experimental desion was group randomized design (GRD) 3 treatments and 3replicationswere used treatments that is A (concentration 0,25\%), B (concentration $0,5 \%$ ), $\mathrm{C}$ (concentration 1\%), $\mathrm{K}$ (control). Test this study by calculating the number of colonies grown on agar medium. The result showed that B treatment $(0.5 \%$ concentration) can inhibit $S$. agalactiae bacteria growth with marked growth of bacteria on TSA (Trypticase soyaagar) medium.
\end{abstract}

Keywords: Streptococcus agalactiae, Cinnamommum burmanii, in vitro

\section{PENDAHULUAN}

Ikan nila (Oreochromis niloticus) merupakan salah satu komoditas air tawar yang memiliki nilai ekonomis tinggi. Produksi ikan nila pada empat tahun terakhir tahun 2010-2014 mengalami peningkatan rata-rata sebesar 21,41\% per tahun (KKP, 2015). Kegiatan intensitifikasi budidaya guna mendukung program industrialisasi perikanan budidaya menimbulkan kendala.

Salah satu kendala dalam pengembangan budidaya ikan nila di Indonesia adalah infeksi Streptococcosis. Infeksi ini disebut jugasyndrome meningoencephalitis (sindrom radang otak dan selaput otak) dan panophthalmitis (radang mata). Penyakit sering menyerang pada budidaya ikan nila yang berdampak pada tingkat kematian ikan berkisar antara30 - 80\% (Evans et al,2002).

Taukhid dan Purwaningsih (2011) menyatakan bahwa penyebab Streptococcosis pada sentra budidaya ikan nilaadalah infeksi bakteri S. agalactiae $(85 \%)$ dan S. iniae (15\%). Gejala yang ditimbukan adalah lemah, warna tubuh gelap, hilang nafsu makan, hilang keseimbangan, kornea mata berwarna pucat, pendarahan pada bagian eksternal serta luka. Selanjutnya dikatakan bahwa secara laboratoris, infeksi $S$. agalactiae pada ikan nila bersifat akut sedangkan infeksi $S$. iniae lebih bersifat kronis. Berdasarkan fakta tersebut dapat diindikasikan bahwa bakteri $S$. agalactiae lebih berpotensi tinggi sebagai penyebab Streptococcosis yang lebih serius pada budidaya ikan.

Upaya pengendalian penyakit pada budidaya ikan, sampai saat ini masih menggunakan antibiotik. Pemakaian antibiotik dalam jangka panjang, tidak terkontrol dan tidak tepat dosis akan berdampk negatif . Dampak negatif yang ditimbulkan adalah munculnya resistensi bakteri, pencemaran lingkungan perairan, dan adanya residu kimia pada ikan konsumsi (Alifuddin, 2002). 
Cara alternatif selain menggunakan antibakteri yaitu dengan menggunakan tanaman fitofarmaka yang bersifat alami serta ramah lingkungan. Salah satu tanaman yang berpotensi sebagai bahan fitofarmaka ialah tanaman kayu manis (Cinnamomum burmani). Bagian dari kayu manis yang telah dimanfaatkan yaitu kulit batang, daun dan minyak atsiri. Kulit kayu manis memiliki kandungan senyawa kimia flavanoid, saponin, tanin dan alkanoid (Azima, et al, 2004).

Rattanachaikunsopon dan Phumkhachorn (2010) menyatakan bahwa kulit kayu manis (C. verum) mampu menghambat bakteri S. iniae. Menurut Gunawan dan Mulyani (2004) minyak atsiri $C$. burmani mengandung sinamil aldehida, eugenol, linalool, kariofilena, dan asam sinamat. Begitu juga dengan daun kayu manis mengandung alkanoid, flavonoid, fenolik hidrokuinon, saponin dan tanin (Sufriadi, 2006).

Beberapa penelitian mengenai penggunaan ekstrak daun kayu manis dilaporkan oleh Sufriadi (2006) dan Safratilofa (2016). Mengenai manfaat daun kayu manis (Cinnamomumburmanni) terhadap khasiat antioksidasimahkota dewa (Phaleria macrocarpa (scheff.) boerl.)selama penyimpanandan potensi ekstrak daun kayu manis Cinnamomum burmanii untuk meningkatkan respon imun ikan patin Pangasianodon hypopthalmus yana diinfeksi Aeromonas hydrophila.

Pemanfaatan daun kayu manis untuk pencegahan infeksi Streptococcosis belum banyak dikembangkan, sehingga perlu dilakukan penelitian lebih lanjut guna mengetahui pengaruh efektivitas daun kayu manis (Cinnamomum burmanii) sebagai antibakteri secara in vitro dan in vivo untuk pencegahan infeksi Streptococcus agalactiae pada ikan nila (Oreochromis niloticus).

\section{TINJAUAN PUSTAKA}

\section{Streptococcus agalactiae}

Klasifikasi bakteri Streptococcus agalactiae menurut Lehmann andNeumann (1896) adalah sebagai berikut :

$\begin{array}{ll}\text { Kingdom } & \text { : Bacteria } \\ \text { Phylum } & \text { :Firmicutes } \\ \text { Class } & \text { : Bacilli } \\ \text { Ordo } & \text { :Lactobacillales } \\ \text { Family } & \text { : Streptococcaceae } \\ \text { Genus } & \text { : Streptococcus } \\ \text { Spesies } & \text { : Streptococcusagalactiae }\end{array}$

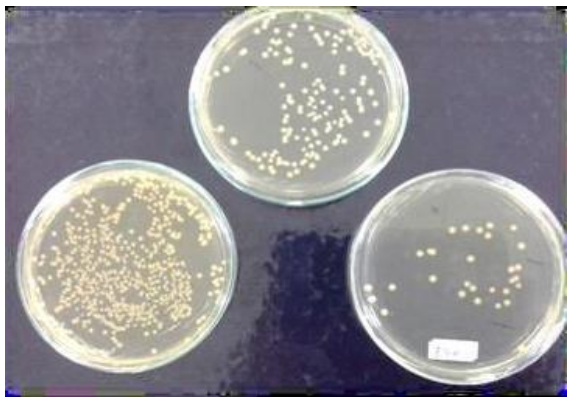

Gambar 1. KoloniStreptococcus galactiae

Streptococcus adalah sel yang bulat atau sferis, tersusun berpasangan atau dalam bentuk rantai, merupakan bakteri gram positif, mampu memproduksi kapsul polisakarida, dan mampu bertahan pada inang dalamtemperatur tinggi (Lehmann dan Neumann, 1896). Streptococcusadalah golongan bakteri yang heterogen. Semua spesiesnya merupakan bakterinon motil, non sporing dan menunjukkan hasil negative untuk tes katalase, dengan syarat nutrisi kompleks. Streptococcus digolongkan berdasarkan kombinasi sifatnya, antara lain sifat pertumbuhan koloni (Gambar 1.), pola hemolisis pada agar darah (hemolisis $\alpha$, hemolisis $\beta$, atau non hemolisis), susunan antigen padat dinding sel yang spesifik untuk golongan tertentu dan reaksi-reaksi biokimia.

\section{Cinnamomum burmanii}

Klasifikasi tanaman kayu manis menurut Rismunandar dan Paimin (2001) adalah sebagai berikut : 
Jurnal Perikanan Pantura (JPP) Volume 1, Nomor 1, Maret 2018

\begin{tabular}{lll}
\hline Divisi & $:$ Gymnospermae \\
Subdivisi & $:$ Spermatophyta \\
Kelas & : Dicotyledonae \\
Sub Kelas & $:$ Dialypetalae \\
Ordo & $:$ Policarpicae & : Lauraceae \\
Famili & $:$ Cinnamomum \\
Genus & $:$ Cinnamomum burmanii
\end{tabular}

Gambar 1. Daun Kayu Manis (Cinnamomum burmaniii)

Cinnamomum sp. merupakan tanaman rempah dari famili Lauranceaeyang terdiri dari beberapa spesies (Rismunandar danPaimin 2001). Tumbuhan ini banyak terdapat di daerah sub tropis dan tropis. Berbentuk pohon dengan tinggi berkisar antara $5-15 \mathrm{~m}$, kulitnya berwarna abu-abu tua dengan bau yang khas dan kayunyaberwarna merah coklat muda.

Daun tunggal dengan tekstur kaku seperti kulit, letak berseling, panjang tangkai daun $0,5-1,5 \mathrm{~cm}$ dengan 3 buah tulang daun yang tumbuh melengkung, berbentuk elips memanjang dengan panjang $4-14 \mathrm{~cm}$ dan lebar $1,5-6 \mathrm{~cm}$, berujung runcing dengan tepi rata, permukaan atas licin berwarna hijau, permukaan bawah bertepung warnanya keabu-abuan. Daun mudah berwarna merah pucat. Bunganya berkelamin ganda atau bunga sempurna dengan warna kuning. Bentuk dan warna daun dapat dilihat pada Gambar 2.

\section{METODOLOGI PENELITIAN}

\section{Tempat dan Waktu}

Penelitian ini dilaksanakan pada bulan Agustus sampai Desember 2017. Uji in vitrodilaksanakan di Laboratorium KaVe Dalegan - Panceng, sedangkan uji in vivodilaksanakan di Laboratorium Prodi Budidaya Perikanan, Universitas Muhammadiyah Gresik.

\section{Prosedur Pelaksanaan Penelitian}

\section{Pembuatan serbuk daun kayu manis (Cinnamomum burmanii)}

Daun kayu manis dikeringkan pada udara terbuka (kering udara) tanpa terkena cahaya matahari langsung untuk menghindari kerusakan bahan aktif yang terdapat pada daun kayu manis. Pengeringan dilakukan sampai daun dapat dihaluskan dan diayak untuk mendapatkan serbuk daun kayu manis.

\section{Penyadiaan bakteri uji}

Isolat bakteri $S$. agalactiae yang digunakan merupakan isolat bakteri $S$. agalactiae N14G berasal dari Balai Riset Perikanan Budidaya Air Tawar dan Penyuluhan Perikanan Sempur, Bogor. Isolat stok bakteri S. agalactiae BHIA di agar miring diremajakan (Fasase) dengan mengkultur isolat pada media agar miring yang dilakukan sebanyak 2 kali. Penyiapan inokulan S. agalactiaedilakukan dengan beberapa tahapan yaitu: 1. Mengkultur isolat bakteri dengan melakukan inokulasi biakan murni bakteri dari media agar miring BHIA ke dalam 10ml media cair TSB (Trypticase soya broth) kemudian diinkubasi pada suhu $29-30^{\circ} \mathrm{C}$ selama24 jam. 2. Biakan yang diinkubasi 24 jam tersebut, kemudian diambil $1 \mathrm{ml}$ dan dimasukkan dalam $9 \mathrm{ml}$ medium TSB baru, yang selanjutnya diinkubasi kembali pada suhu $29-30^{\circ} \mathrm{C}$ selama24 jam setelah itu bakteri dipanen.

\section{Uji Antibakteri serbuk daun kayu manis secara in vitro}

Dwidjoseputro (2005) menyatakan bahwa viabilitas bakteri dihitung dengan menggunakan metode TPC (Total Plate Count). Persiapan yang dilakukan yakni menyiapkan ependofe 
sebanyak 4 buah. Masing-masing ependofe diisi dengan akuades steril dan ditambahkan serbuk kayu manis sesuai dengan konsentrasi yang akan diuji yaitu $0,25 \%, 0,5 \%$ dan $1 \%$.

Pada perlakuan kontrol diisi 0,9 ml akuades tanpa daun kayu manis. Pada semua perlakuan ditambahkan 0,1 ml suspensi bakteri, kemudian dihomogenkan dan diinkubasi selama 24 jam. Pada hari kedua dari masing-masing campuran bakteri dengan serbuk daun kayu manis diencerkan berkala hingga $10^{6} \mathrm{CFU} / \mathrm{ml}$ dan disebarkan pada media TSA sebanyak $50 \mu \mathrm{l}$. Pengulangan $3 x$ pada setiap perlakuan.

Selanjutnya sebaran bakteri pada media TSA diinkubasi kembali selama 48-72 jam. Pada hari ketiga dihitung jumlah koloni yang tumbuh pada media TSA.

\section{Parameter Yang Diamati}

Parameter yang diamati dalam penelitian ini adalah Daya antibakteri daun kayu manis terhadap pertumbuhan bakteri $S$. agalavtiae. Kepadatan bakteri dihitung dengan rumus :

$\mathrm{CFU} / \mathrm{ml}=\sum$ koloni $\mathrm{X}$ faktor pengenceran

\section{Analisis Data}

Data yang diproleh selama penelitian dianalisa secara deskriptif

\section{HASIL DAN PEMBAHASAN}

\section{Daya Anti Bakteri Daun Kayu Manis Terhadap Pertumbuhan S. agalactiae}

Dari hasil uji in vitro serbuk daun kayu manis terhadap bakteri Streptococcus agalactiae diketahui bahwa penggunaan serbuk daun kayu manis dengan konsentrasi 0,5\% dapat menghambat pertumbuhan bakteri $S$. agalactiae, hal ini ditandai dengan tidak adanya bateri yang tumbuh pada media TSA ( Trypticase soya agar) seperti yang terlihat pada Gambar 3 dan Gambar 4.

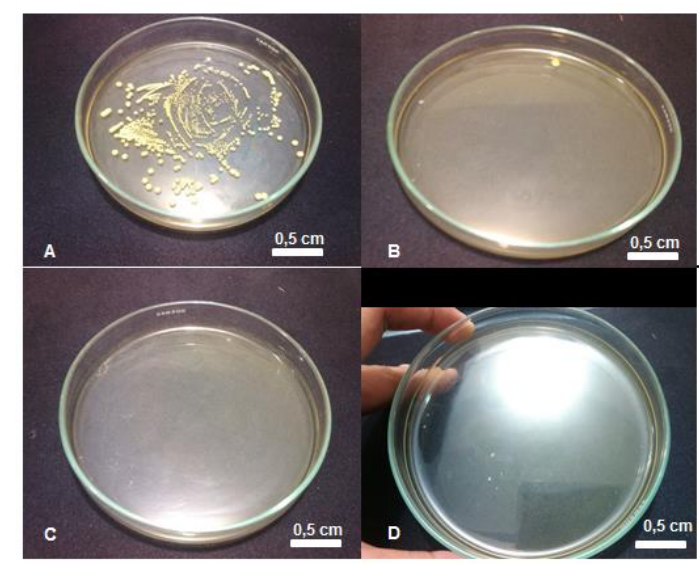

Gambar 3.Pertumbuhan Bakteri S. agalactiae dengan Pemberian Daun Kayu Manis Berbagai Konsentrasi (K) Kontrol (A) Daun Kayu Manis 0,25\% (B) 0,5\% dan (C) $1 \%$. 
Jurnal Perikanan Pantura (JPP) Volume 1, Nomor 1, Maret 2018

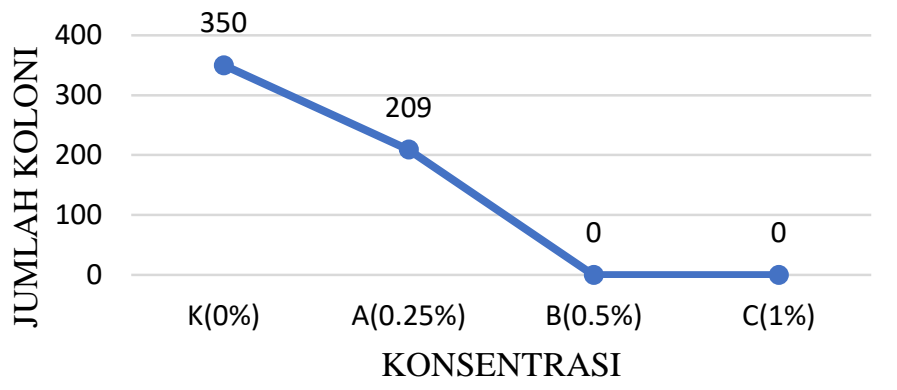

Gambar 4. Grafik hasil pengamatan uji in vitro pemberian daun kayu manis konsentrasi berbeda terhadap pertumbuhan bakteri Streptococcus agalactiae

Pada penelitian ini uji antibakteria daun kayu manis yang dilakukan menggunakan metode Total Plate Count (TPC), terlihat bahwa tidak ada bakteri yang tumbuh pada media TSA (Trypticase Soy Agar) mulai dari dosis 0,5\% (Gambar 8.). Hal ini berhubungan dengan zat aktif yang terkandung dalam daun kayu manis yang dapat menghambat pertumbuhan bakteri Streptococcus agalactiae. Zat aktif yang terkandung dalam daun kayu manis seperti transinamaldehid, polifenol, flavonoid, saponin, tannin. Penelitian Safratilofa (2015) menyatakan kandungan kimia dari ekstrak daun kayu manis adalah saponin tanin, fenolik, flavonoid, alkanoid, steroid dan glikosida (Tabel 1.).

Hasil penelitian Rattanachaikunsopon dan Phumkhanchorn (2010) menunjukan bahwa $1,57 \%$ minyak atsiri kayu manis jenis Cinamomum verum yang mengandung sinamaldehid 90,24\% dapat menghambat pertumbuhan Streptococcus iniae. Mekanisme aktivitas antimikroba sinamaldehid terhadap $S$. iniae diduga melalui perusakan permukaan sel bakteri (Kim et al, 2004). Menghambat aktivitas enzim amino acid dekarboksilase, mengikat protein seluler sehingga tidak bekerja dengan baik (Wendakoon dan Sakaguchi 1995)

Kandungan zat aktif dari daun kayu manis ini diduga dapat menghambat pertumbuhan bakteri. Senyawa-senyawa dalam zat aktif tersebut memiliki sifat antibakteria dengan mekanisme yang berbeda. Saponin bekerja merusak membran plasma bakteri. Tanin memiliki aktivitas antibakteri yang berhubungan dengan kemampuannya untuk menginaktifkan adhesin sel mikroba juga menginaktifkan enzim dan menggangu transpor protein pada pada lapisan dalam sel.

Flavanoidmerupakan senyawa antibakteri yang memiliki kemampuan untuk mengikat, membentuk kompleks dengan protein ekstra seluler dan terlarut, dan juga membentuk kompleks dengan dinding sel bakteri, serta memiliki sifat lipofilik yang dapat merusak membrane bakteri.Polifenol memiliki mekanisme anti bakteri yang menyebabkan denaturasi protein, menghambat pembentukan protein sitoplasma protein sitoplasma dan asam nukleat serta menghambat ikatan ATP-ase pada membran sel. Selain itu, daun kayu manis terdapat kandungan minyak atsiri yag bersifat antibakteri.

Hasil penelitian Safratilofa (2015) menyimpulkan bahwa ekstrak daun kayu manis (Cinnamomum burmanii) dapat menghambat pertumbuhan bakteri Aeromonas hydrophila. Bakteri tidak tumbuh mulai osis 5\% pemberian kayu manis. Penelitian lain oleh Puspita (2014) menyatakan bahwa ekstrak kayu manis (cinnamomum burmanii) berpengaruh dalam menghambat pertumbuhan streptococcus mutans. Penelitian Angelica (2013) menyatakan bahwa ekstrak daun kayu manis dapat menghambat bakteri Escherichia coli dan Staphylococcus aureus. 
Jurnal Perikanan Pantura (JPP) Volume 1, Nomor 1, Maret 2018

\section{KESIMPULAN DAN SARAN}

\section{Kesimpulan}

Penggunaan serbuk daun kayu manis dapat menghambat pertumbuhan bakteri Streptococcus agalactiae mulai konsentrasi $0,5 \%$.

\section{Saran}

Disarankan untuk melakukan penelitian lanjutan untuk melihat gambaran darah ikan terhadap pengaruh serbuk daun kayu manis dalam pencegahan serta pengobatan terhadap penyakit Streptococcosis

\section{DAFTAR PUSTAKA}

Alifuddin, M. 2002. Imunostimulasi Pada Hewan Akuatik. Jurnal Akuakultur Indonesia. 1(2): $87-92$.

Angelica N. 2013. Aktivitas antibakteri etanol daun kayu manis dan batang kayu manis (Cinnamomum burmanii (Nees \& Th. Nees)) terhadap Escherichia coli dan Staphylococcus aureus. Jurnal Ilmiah Mahasiswa Universitas Surabaya. 2(2): 1-8

Dwidjoseputro, D. 2005. Dasar-dasar Mikrobiologi. Djambatan: Jakarta.

Evans JJ, Klesius PH, Glibert PM, Shoemaker CA, Al SarawiMA, Landsberg J, Duremdez R, Al Marzouk A and AlZenki S. 2002. Characterization of beta-haemolyticGroup B Streptococcus agalactiae in cultured seabream,Sparus auratus (L.) and wild mullet, Liza klunzingeri(Day), in Kuwait. Journal of Fish Diseases 25, 505-513.

Kementrian Kelautan dan Perikanan. 2015. Kelautan dan Perikanan Dalam Angka 2015. Pusat Data, Statistik dan Informasi. Jakarta. Hlm xxviii-308.

Kim HO, Park SW, Park HD. 2004. Inactivation of Escherichia coli O157:H7 by cinnamic aldehyde purified from Cinnamomum cassia shoot. Food Microbiol 21:105-110

Lehmann KB, Neumann R. 1896. Atlas und Grundriss derBakteriologie und Lehrbuch der speziellenbakteriologischen Diagnostik. 1st ed. J.F.Lehmann, Munchen.

Puspita A. 2014. Pengaruh konsentrasi ekstrak kayu manis (cinnamomum burmanni) dalam menurunkan pertumbuhan streptococcus mutans secara in vitro. Naskah publikasi disusun untuk dipublikasikan pada jurnal ilmiah fakultas kedokteran gigi Universitas Muhammadiyah Surakarta.

Rattanachaikunsopon P dan Phumkhachorn P. 2010. Potential of cinamon Cinamomum verum oil to control streptococcus iniae infection in tilapia Oreochromis niloticus. Japan Fish Sci. 76: 287-293.

Rismunandar, Paimin FB. 2001. Кауи ManisBudidaya dan Pengolahan. PenebarSwadaya. Jakarta.

Safratilofa. 2015. Potensi ekstrak daun kayu manis Cinnamomum burmaniii untuk meningkatkan respon imun ikan patin Pangasianodon hypopthalmus yang diinfeksi Aeromonas hydrophila. Tesis. Institut Pertanian Bogor. Bogor.

Sufriadi A. 2006. Manfaat daun kayu manis Cinnamomum burmanni terhadap khasiat antioksidasi mahkota dewa Phaleria macrocarpa (Scheff.) Boerl) selama penyimpanan. [Skripsi]. Bogor [ID]. Institut Pertanian Bogor.

Taukhid danPurwaningsih, U. 2011.Penapisan isolat bakteriStreptococcus spp. sebagai kandidat antigen dalam pembuatanvaksin, serta efikasinya untuk pencegahan penyakitstreptococciasis pada ikan nila, Oreochromis niloticus.Jurnal Riset Akuakultur. Volume 6 Nomor 1, hal 103-118.

Wendakoon CN, Sakaguchi M. 1995. Inhibition of amino acid decarboxylase activity of Enterobacter aerogenes by active components in spices. J Food Prot 58:280-283 